Check for updates

Cite this: RSC Adv., 2018, 8, 20488

\title{
Purification and identification of antioxidative peptides from mackerel (Pneumatophorus japonicus) protein
}

\author{
Xueqin Wang, (D) abc Huahua Yu, ${ }^{\text {abc }}$ Ronge Xing, ${ }^{a b c}$ Xiaolin Chen, ${ }^{\text {abc }}$ Rongfeng Li, ${ }^{a b c}$ \\ Kecheng Li, ${ }^{a b c}$ Song Liu ${ }^{\mathrm{abc}}$ and Pengcheng $\mathrm{Li}^{\star \mathrm{abc}}$
}

\begin{abstract}
This study reports the preparation, purification and identification of an antioxidative peptide from mackerel (Pneumatophorus japonicus) protein. Neutrase was chosen as the optimum protease, with the highest cellular antioxidant activity of 53.65\%. The optimal hydrolysate conditions for mackerel protein hydrolysates (MPH) according to response surface methodology were an enzyme concentration of $1203.2 \mathrm{U} \mathrm{g}^{-1}$, extraction time of $4.53 \mathrm{~h}, \mathrm{pH}$ of 7.26 , water/material ratio of $5.22 \mathrm{v} / \mathrm{w}$ and extraction temperature of $43.72{ }^{\circ} \mathrm{C}$. MPH was separated using ultrafiltration membranes, and the fraction MPH-III with molecular weight below 3500 Da showed the highest cellular antioxidant activity. Five fractions were separated from MPH-III on a Sephadex G-25 column, and MPH-III-2, exhibiting the highest cellular antioxidant activity, was further separated with an XBridge ${ }^{\circledR}$ peptide BEH C18 column. The MPH-III-2-6 separated from RP-HPLC was further analysed by Thermo Scientific $Q$ Exactive mass spectrometer, and the heptapeptide LDIQKEV $(843.5 \mathrm{Da})$ and the octapeptide TAAIVNTA $(759.4 \mathrm{Da})$ were identified. The results of this study offer a promising alternative to produce natural antioxidative peptides from fish protein hydrolysate, which may be utilized as functional ingredients in food systems.
\end{abstract}

Received 19th April 2018

Accepted 29th May 2018

DOI: 10.1039/c8ra03350a

rsc.li/rsc-advances water/material ratio), since these factors determine the peptide profile that is essentially responsible for any antioxidant and functional activities. ${ }^{9}$ Hence, it is important to choose the appropriate conditions during hydrolysis.

Mackerel (Pneumatophorus japonicus) is an important foodstuff that is consumed worldwide. ${ }^{10}$ It is low-cost and has high productivity; thus, there have been many studies of the processing and utilization of mackerel in recent years, including the pretreatment and benefits of mackerel, ${ }^{11}$ antiproliferative activity, ${ }^{12}$ anti-hypertensive activity, ${ }^{13}$ and antimicrobial activity ${ }^{\mathbf{1 4}}$ of mackerel. In addition, several researchers have focused on the antioxidant activity of mackerel and showed that mackerel could be used as a good source of antioxidant peptides. ${ }^{15}$

Additionally, antioxidant activity is closely related to amino acid composition and the sequence, molecular weight and configuration of peptides. ${ }^{\mathbf{1 6}}$ Hence, the purification of the mackerel peptide should be explored. Although Sampath Kumar et al. ${ }^{17}$ purified and identified the constituent amino acids of horse mackerel (Magalaspis cordyla) skin protein hydrolysate, the isolation of peptides from mackerel (Pneumatophorus japonicus) muscle protein has not been thoroughly elucidated to date. Therefore, the objectives of this study were to prepare mackerel (Pneumatophorus japonicus) muscle protein hydrolysates, evaluate their cellular antioxidant activity and further purify and identify the antioxidant peptides.
${ }^{a}$ CAS Key Laboratory of Experimental Marine Biology, Institute of Oceanology, Chinese Academy of Sciences, No. 7, Nanhai Road, Qingdao 266071, China. E-mail: pcli@qdio. ac.cn; Fax: +86 532 82968951; Tel: +8653282898707

${ }^{b}$ Laboratory for Marine Drugs and Bioproducts, Qingdao National Laboratory for Marine Science and Technology, No. 1, Wenhai Road, Qingdao 266237, China

${ }^{c}$ Center for Ocean Mega-Science, Chinese Academy of Sciences, China 

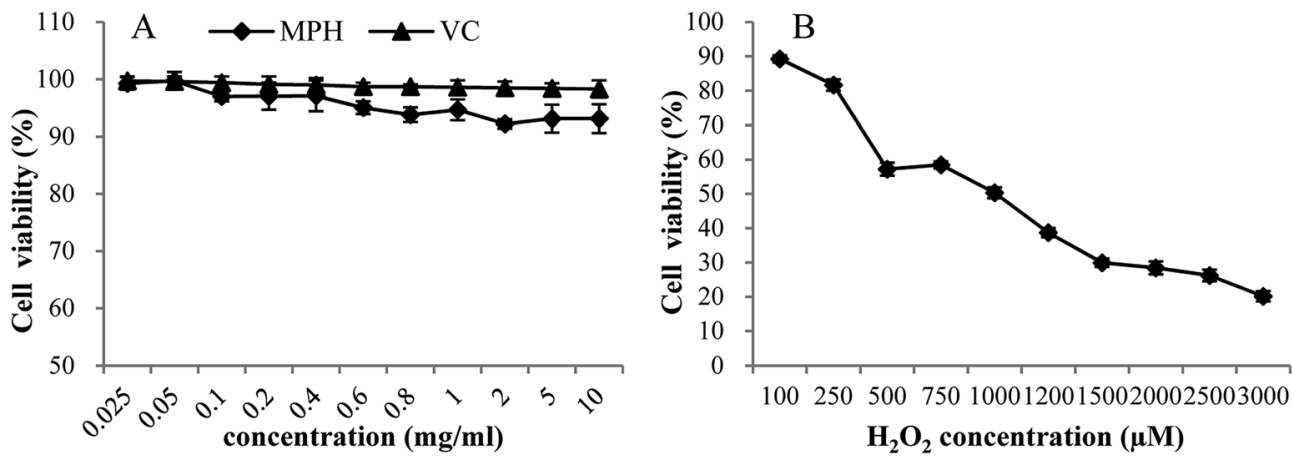

Fig. 1 Dose-dependent toxic effects of $\mathrm{MPH}, \mathrm{VC}$ and $\mathrm{H}_{2} \mathrm{O}_{2}$ on HepG2 cell viability. Data were presented as the means $\pm \mathrm{SD}$.

\section{Material and methods}

\subsection{Materials and chemicals}

Fresh mackerel (Pneumatophorus japonicus), 210-260 g per fish, were purchased from a seafood market in Qingdao, China. Whole fish were transported on ice to reduce histamine production. Upon arrival, the fish were washed and the muscle (without head, tail, skin, bones and blood) was collected, sliced, minced and stored in plastic bags at $-20{ }^{\circ} \mathrm{C}$ until use. Five proteases (pepsin, trypsin, papain, flavourzyme and neutrase) were provided by Kangbaotai Co. (Hubei, China). Both 1,1diphenyl-2-picrylhydrazyl (DPPH) and trifluoroacetic acid (TFA) were purchased from the Sigma Chemical Co. (St Louis, MO, USA). The ultrafiltration (UF) system and UF membranes with molecular weight cut-offs (MWCO) of 10000 Da and 3500 Da were purchased from the Laungy Co., Ltd. (Shanghai, China). The fraction collector and computer ultraviolet (UV) detector were purchased from the Shanghai huxi Analysis Instrument Factory Co., Ltd. (Shanghai, China). The human hepatoma cell line HepG2 was obtained from Qingdao University (Shandong, China). The growth medium and antibiotics for cell culture experiments were purchased from HyClone, USA. Foetal bovine serum (FBS), used in cell culturing, was purchased from Gibco, Australia. The water was distilled and purified using a Milli-Q Water Purification System (Millipore, Bedford, MA, USA). All other chemicals and solvents were of analytical grade.

\subsection{Preparation of mackerel protein hydrolysates (MPH)}

The antioxidant capacity of protein hydrolysates was mainly determined according to the raw material and the extent of enzymatic treatment. ${ }^{18}$ In this section, five proteases, pepsin, trypsin, papain, flavourzyme and neutrase, were used to determine the optimal enzyme. Minced mackerel was mixed with deionized water at a ratio of $1: 10 \mathrm{v} / \mathrm{w}$. The mixtures were adjusted to the required $\mathrm{pH}$ with $0.01 \mathrm{~mol} \mathrm{~L}^{-1} \mathrm{NaOH}$ or $\mathrm{HCl}$ and heated in a water bath to the required temperature before proteases were added in a proper proportion based on enzyme activity. The hydrolysis reactions were performed in a shaking incubator. At the end of the hydrolysis period, the mixtures were heated in boiling water for $10 \mathrm{~min}$ to inactivate the proteases. Next, the hydrolysates were centrifuged at $18000 \times g\left(4{ }^{\circ} \mathrm{C}\right)$ for $30 \mathrm{~min}$ and the supernatants were stored at $4{ }^{\circ} \mathrm{C}$ before use. Among the five hydrolysates, the one with the highest cellular antioxidant activity was chosen for further optimization according to a BBD using response surface methodology (RSM).

\subsection{Optimization of MPH preparative conditions}

Extraction optimization in generally was performed using RSM. ${ }^{19}$ In this section, five major factors (enzyme concentration, $\mathrm{pH}$, extraction temperature, extraction time, water/ material ratio) were selected for the single factor experiments. Next, on the basis of the single factor experiments, the five independent variables at five levels were designed in a BBD by RSM. Design Expert (Trial Version 8.0.6; State-Ease Inc., Minneapolis, MN, USA) was used to analyse and calculate the predicted responses and experimental design for the cellular antioxidant activity. The responses obtained from each set of experimental designs were analyzed by multiple regressions to fit the following quadratic polynomial model:

$$
Y=\beta_{0}+\sum_{i=1}^{k} \beta_{i} X_{i}+\sum_{i=1}^{k} \beta_{i i} X_{i}^{2}+\sum \sum_{i<j} \beta_{i j} X_{i} X_{j}
$$

where $Y$ is the response variable, $\beta_{0}$ is a constant, $\beta_{i}, \beta_{i i}$ and $\beta_{i j}$ are the linear, quadratic, and interaction coefficients, respectively, while $X_{i}$ and $X_{j}$ are the coded independent variables.

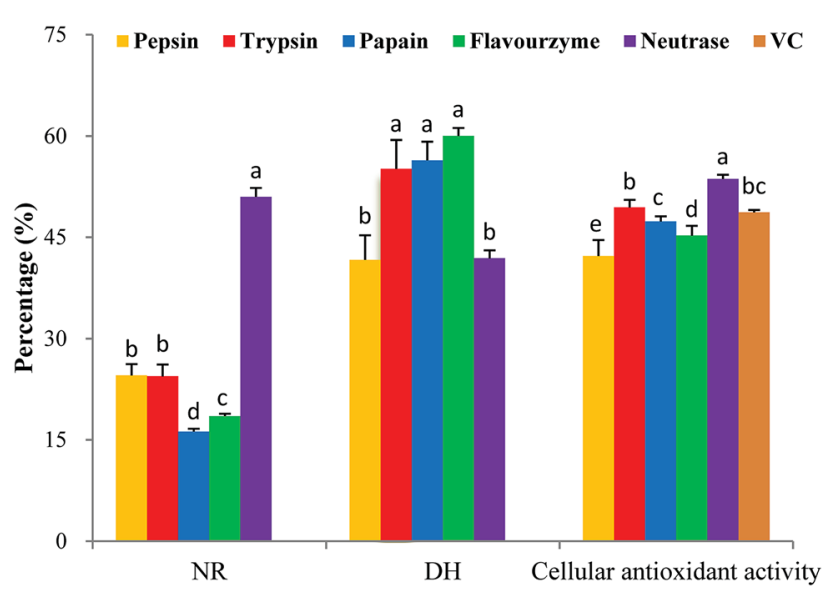

Fig. 2 Cellular antioxidant activity, DH and NR of MPH prepared by different proteases. Data are presented as means \pm SD. Bar graphs followed by different letters indicate significant differences $(P<0.05)$. $\mathrm{DH}$ indicates degree of hydrolysis, NR indicates nitrogen recovery. The concentrations of $\mathrm{MPH}$ and $\mathrm{VC}$ were $10 \mathrm{mg} \mathrm{mL}^{-1}$. 

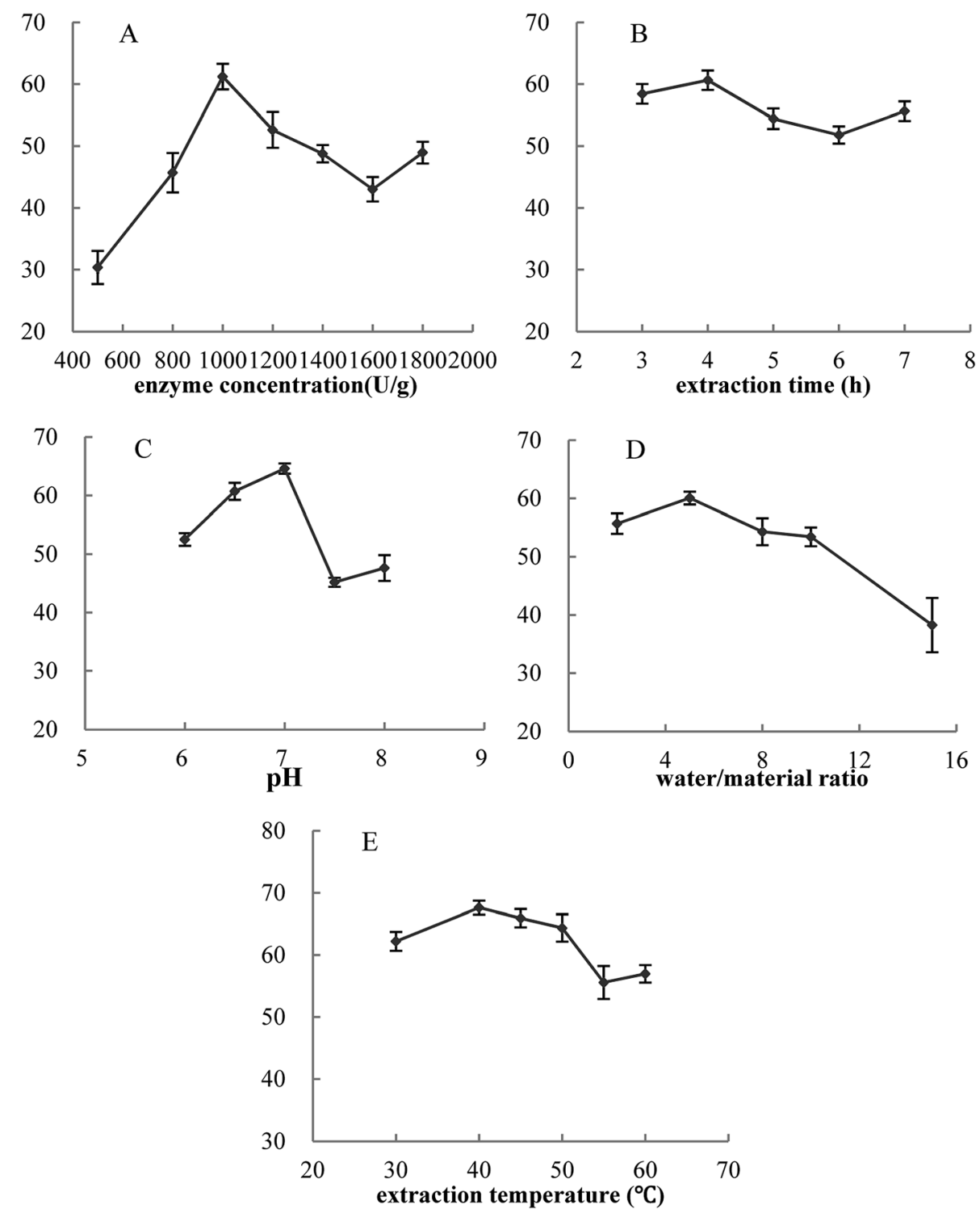

Fig. 3 Effects of five single factors on cellular antioxidant activity. $Y$-axis was cellular antioxidant activity. The concentration of MPH and VC was $10 \mathrm{mg} \mathrm{mL}^{-1}$. Data are presented as means $\pm \mathrm{SD}$.

According to the Design Expert Software, an analysis of variance table was generated, and the effect and regression coefficients of linear, quadratic and interaction terms were determined. $P$ values greater than 0.05 indicated the model terms were not significant. The regression coefficient was used to perform statistical calculations, and the generated 3D surface was determined from the fitted polynomial equation.

\subsection{Determination of degree of hydrolysis (DH)}

The degree of hydrolysis was evaluated as the proportion (\%) of $\alpha$-amino nitrogen with respect to the total nitrogen in the sample. ${ }^{20}$ Analyses were repeated three times.

\subsection{Determination of nitrogen recovery (NR)}

After hydrolysis, the supernatant was obtained by centrifugation at $4000 \times g\left(4{ }^{\circ} \mathrm{C}\right)$ for $20 \mathrm{~min}$. The volume of the soluble fraction was recorded, and the total nitrogen in the supernatant was determined using the Kjeldahl method. ${ }^{21} \mathrm{NR}$ was calculated using the following equation: ${ }^{22}$

$$
\begin{aligned}
\text { NR }(\%)= & \text { Total nitrogen in supernatant }(\mathrm{mg}) / \\
& \text { total nitrogen in substrate }(\mathrm{mg}) \times 100
\end{aligned}
$$

\subsection{Antioxidant analyses in HepG2 cells}

2.6.1 Cytotoxicity effect of $\mathrm{H}_{2} \mathrm{O}_{2}$ or MPH on HepG2 cells. The inhibition of HepG2 was assessed by the MTT assay described by Yarnpakdee et al., with a few modifications. ${ }^{23}$ The HepG2 cells were seeded into 96-well culture plates $\left(4 \times 10^{3}-1 \times 10^{4}\right.$ per well $)$ and incubated at $37{ }^{\circ} \mathrm{C}$ in a humidified atmosphere with $5 \% \mathrm{CO}_{2}$ for $24 \mathrm{~h}$. Next, the HepG2 cells were incubated with $\mathrm{H}_{2} \mathrm{O}_{2}$ or MPH at various concentrations $(100 \mu \mathrm{L})$ for another $24 \mathrm{~h}$, and the HepG2 
Table 1 Experimental design and result of response surface ${ }^{a}$

\begin{tabular}{|c|c|c|c|c|c|c|}
\hline Run numbers & A & B & $\mathrm{C}$ & D & $\mathrm{E}$ & $\begin{array}{l}\text { Cellular antioxidant } \\
\text { activity }^{b}(\%)\end{array}$ \\
\hline 1 & 600 & 2 & 7 & 5 & 40 & 45.47 \\
\hline 2 & 1400 & 2 & 7 & 5 & 40 & 49.20 \\
\hline 3 & 600 & 6 & 7 & 5 & 40 & 51.86 \\
\hline 4 & 1400 & 6 & 7 & 5 & 40 & 55.71 \\
\hline 5 & 1000 & 4 & 5 & 1 & 40 & 35.45 \\
\hline 6 & 1000 & 4 & 9 & 1 & 40 & 43.41 \\
\hline 7 & 1000 & 4 & 5 & 9 & 40 & 35.69 \\
\hline 8 & 1000 & 4 & 9 & 9 & 40 & 39.32 \\
\hline 9 & 1000 & 2 & 7 & 5 & 30 & 38.82 \\
\hline 10 & 1000 & 6 & 7 & 5 & 30 & 47.03 \\
\hline 11 & 1000 & 2 & 7 & 5 & 50 & 47.01 \\
\hline 12 & 1000 & 6 & 7 & 5 & 50 & 53.40 \\
\hline 13 & 600 & 4 & 5 & 5 & 40 & 38.45 \\
\hline 14 & 1400 & 4 & 5 & 5 & 40 & 45.51 \\
\hline 15 & 600 & 4 & 9 & 5 & 40 & 46.20 \\
\hline 16 & 1400 & 4 & 9 & 5 & 40 & 53.67 \\
\hline 17 & 1000 & 4 & 7 & 1 & 30 & 45.80 \\
\hline 18 & 1000 & 4 & 7 & 9 & 30 & 47.55 \\
\hline 19 & 1000 & 4 & 7 & 1 & 50 & 48.92 \\
\hline 20 & 1000 & 4 & 7 & 9 & 50 & 53.00 \\
\hline 21 & 1000 & 2 & 5 & 5 & 40 & 39.14 \\
\hline 22 & 1000 & 6 & 5 & 5 & 40 & 46.59 \\
\hline 23 & 1000 & 2 & 9 & 5 & 40 & 42.39 \\
\hline 24 & 1000 & 6 & 9 & 5 & 40 & 48.21 \\
\hline 25 & 600 & 4 & 7 & 1 & 40 & 39.14 \\
\hline 26 & 1400 & 4 & 7 & 1 & 40 & 49.50 \\
\hline 27 & 600 & 4 & 7 & 9 & 40 & 44.15 \\
\hline 28 & 1400 & 4 & 7 & 9 & 40 & 55.32 \\
\hline 29 & 1000 & 4 & 5 & 5 & 30 & 41.46 \\
\hline 30 & 1000 & 4 & 9 & 5 & 30 & 42.74 \\
\hline 31 & 1000 & 4 & 5 & 5 & 50 & 47.43 \\
\hline 32 & 1000 & 4 & 9 & 5 & 50 & 52.79 \\
\hline 33 & 600 & 4 & 7 & 5 & 30 & 48.53 \\
\hline 34 & 1400 & 4 & 7 & 5 & 30 & 53.73 \\
\hline 35 & 600 & 4 & 7 & 5 & 50 & 54.05 \\
\hline 36 & 1400 & 4 & 7 & 5 & 50 & 56.88 \\
\hline 37 & 1000 & 2 & 7 & 1 & 40 & 40.97 \\
\hline 38 & 1000 & 6 & 7 & 1 & 40 & 50.58 \\
\hline 39 & 1000 & 2 & 7 & 9 & 40 & 45.38 \\
\hline 40 & 1000 & 6 & 7 & 9 & 40 & 50.10 \\
\hline 41 & 1000 & 4 & 7 & 5 & 40 & 56.55 \\
\hline 42 & 1000 & 4 & 7 & 5 & 40 & 56.19 \\
\hline 43 & 1000 & 4 & 7 & 5 & 40 & 56.67 \\
\hline 44 & 1000 & 4 & 7 & 5 & 40 & 60.68 \\
\hline 45 & 1000 & 4 & 7 & 5 & 40 & 61.53 \\
\hline 46 & 1000 & 4 & 7 & 5 & 40 & 64.08 \\
\hline
\end{tabular}

${ }^{a} \mathrm{~A}, \mathrm{~B}, \mathrm{C}, \mathrm{D}$ and $\mathrm{E}$ meant enzyme concentration $\left(\mathrm{U} \mathrm{g}^{-1}\right)$, extraction time (h), $\mathrm{pH}$, water/material ratio $(\mathrm{v} / \mathrm{w})$ and extraction temperature $\left({ }^{\circ} \mathrm{C}\right)$. Data represented mean of three measured values.

cells without $\mathrm{H}_{2} \mathrm{O}_{2}$ or MPHs were used as a negative control. After that step, each well was added $20 \mu \mathrm{L}$ of MTT $\left(5 \mathrm{mg} \mathrm{mL}^{-1}\right)$ and incubated for $3 \mathrm{~h}$. After the removal of MTT, dimethyl sulfoxide (DMSO) (150 $\mu \mathrm{L}$ per well) was added, and the mixture was shaken for $10 \mathrm{~min}$. The absorbance was measured on a microplate reader (Bio-Rad, USA) at a wavelength of $490 \mathrm{~nm}$. Vitamin C (VC) was used as a positive control. Measurements were performed four times, and the cytotoxicity was evaluated.
2.6.2 Cell viability determination. The HepG2 cells were seeded into 96 -well culture plates $\left(4 \times 10^{3}-1 \times 10^{4}\right.$ per well $)$ and incubated at $37{ }^{\circ} \mathrm{C}$ in a humidified atmosphere with $5 \% \mathrm{CO}_{2}$ for 24 h. The HepG2 cells were treated with $\mathrm{MPH}$ at a certain concentration $(100 \mu \mathrm{L})$ for $24 \mathrm{~h}$, after which the cells were treated with $1000 \mu \mathrm{M} \mathrm{H}_{2} \mathrm{O}_{2}(100 \mu \mathrm{L})$ for another $24 \mathrm{~h}$. The culture medium was removed, and the cell viability was evaluated by MTT assay, as described above. The cellular antioxidant activity was calculated as follows:

Cellular antioxidant activity $(\%)=\left(A_{1}-A_{0}\right) /\left(A_{2}-A_{0}\right) \times 100$,

where $A_{1}$ was the absorbance with $\mathrm{MPH}$ and $\mathrm{H}_{2} \mathrm{O}_{2}, A_{2}$ was the absorbance without $\mathrm{MPH}$ and $\mathrm{H}_{2} \mathrm{O}_{2}$, and $A_{0}$ was the absorbance with $\mathrm{H}_{2} \mathrm{O}_{2}$. Vitamin $\mathrm{C}$ (VC) was used as a positive control. The measurements were performed four times.

\subsection{Hydroxyl radical scavenging activity}

The scavenging activity of the MPH supernatant on hydroxyl radicals was tested using the method described by Jin et al. ${ }^{24}$ with several modifications. Briefly, the reaction mixture contained $1.0 \mathrm{~mL}$ of phosphate buffer (PBS, $0.15 \mathrm{~mol} \mathrm{~L}^{-1}$, $\mathrm{pH} 7.4$ ), $1.0 \mathrm{~mL}$ of safranine $\mathrm{T}(1.0 \mathrm{mM}), 0.5 \mathrm{~mL}$ of EDTA-FeSO ${ }_{4}\left(2.0 \mathrm{mmol} \mathrm{L}^{-1}\right)$ and $1.0 \mathrm{~mL}$ of $\mathrm{MPH}$ at a certain concentration. After sufficient mixing, $1.0 \mathrm{~mL}$ of $\mathrm{H}_{2} \mathrm{O}_{2}(3 \%)$ was added to the mixture. Following incubation at $37{ }^{\circ} \mathrm{C}$ for $30 \mathrm{~min}$, the absorbance of the mixture was measured at $520 \mathrm{~nm}$. The hydroxyl radical scavenging activity was calculated as: scavenging rate $(\%)=\left[\left(A_{1}-A_{0}\right) /\left(A_{2}-A_{0}\right)\right] \times 100$, where $A_{1}$ was the absorbance of the $\mathrm{MPH}$ with $\mathrm{H}_{2} \mathrm{O}_{2}, A_{2}$ was the absorbance without $\mathrm{H}_{2} \mathrm{O}_{2}$, and $A_{0}$ was the absorbance of the control. Both $A_{0}$ and $A_{2}$ were mixtures with sample solution replaced by deionized water. VC was used as a positive control. All experiments were performed in triplicate.

\subsection{DPPH radical scavenging activity}

The DPPH radical scavenging activities of the MPH supernatant were determined as described by Blois ${ }^{25}$ with slight modifications. Briefly, $1.0 \mathrm{~mL}$ of DPPH $\left(0.1 \mathrm{mmol} \mathrm{L}^{-1}\right)$ diluted in ethanol was added to $3.0 \mathrm{~mL}$ of $\mathrm{MPH}$ at a certain concentration. After vigorous shaking, the mixture was left to stand for $30 \mathrm{~min}$, and the absorbance was measured at $517 \mathrm{~nm}$. The DPPH radical scavenging activity was calculated as follows:

Table 2 ANOVA for response surface quadratic model

\begin{tabular}{lcclll}
\hline Variables & $\begin{array}{c}\text { Sum of } \\
\text { squares }\end{array}$ & DF & $\begin{array}{l}\text { Mean } \\
\text { square }\end{array}$ & $F$ value & $P$ value \\
\hline Model & 1912.47 & 20 & 95.62 & 10.13 & $<0.0001$ \\
Residual & 236.10 & 25 & 9.44 & & \\
Lack of fit & 182.24 & 20 & 9.11 & 1 & 0.6473 \\
Pure error & 53.86 & 5 & 10.77 & & \\
Cor total & 2148.57 & 45 & & & \\
$R^{2}$ & 0.8901 & & & & \\
Adj. $R^{2}$ & 0.8022 & & & & \\
Pred. $R^{2}$ & 0.6246 & & & & \\
Adeq precision & 11.189 & & & & \\
CV\% & 6.35 & & &
\end{tabular}



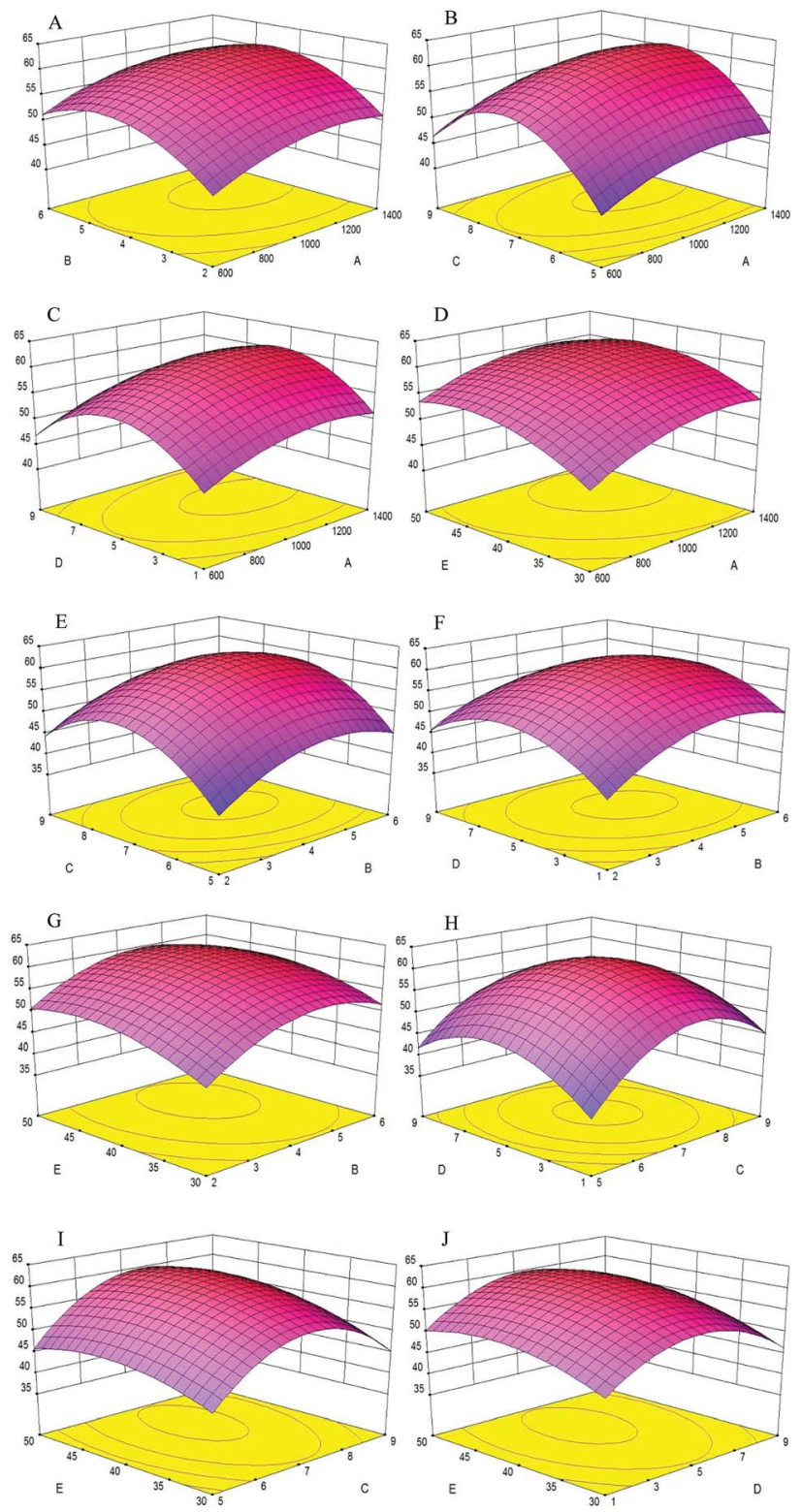

Fig. 4 Response surface plots showing the effects of variables on the cellular antioxidant activity of $\mathrm{MPH}$. $X$-axis and $Y$-axis: $A$ (enzyme concentration); $B$ (extraction time); $C(\mathrm{pH}) ; D$ (water/material ratio); $E$ (extraction temperature). $Z$-axis: cellular antioxidant activity (\%).

scavenging rate $(\%)=\left[1-\left(A_{1}-A_{0}\right) /\left(A_{2}-A_{0}\right)\right] \times 100$, where $A_{0}$ was the absorbance without DPPH, $A_{1}$ was the absorbance in the presence of the MPH, and $A_{2}$ was the absorbance of the control (without MPH). VC was used as a positive control. All experiments were performed in triplicate.

\subsection{Purification of MPH}

2.9.1 Ultrafiltration. UF is a common method to separate hydrolysates into fractions of a higher given activity. ${ }^{26}$ UF was performed using an Amicon model LNG-UF-101 (Laungy Corp., Shanghai, China). To obtain a hydrolysate fraction with both a desirable molecular size and a functional property, the hydrolysate was fractionated using two different UF membranes with the MWCO of $10000 \mathrm{Da}$ and $3500 \mathrm{Da}$, respectively. The fractions were designed as follows: MPH-I (>10000 Da), MPH-II (3500-10 $000 \mathrm{Da})$ and MPH-III (<3500 Da). Filtrates were freezedried and stored at $-20^{\circ} \mathrm{C}$ for further purification and cellular antioxidant activity test.

2.9.2 Gel filtration chromatography. MPH-III (600 mg) was dissolved in distilled water $(2 \mathrm{~mL})$, and the mixture was filtered through a $0.22 \mu \mathrm{m}$ polyether sulfone filter membrane $(25 \mathrm{~mm}$, id.) (Jingteng®, Tianjin, China). The filtrate was loaded onto a gel filtration column $(2.6 \times 80 \mathrm{~cm})$ (Sephadex G-25 Fine, GE Healthcare Bio-Science AB, Uppsala, Sweden) with distilled water at a flow rate of $0.5 \mathrm{~mL} \mathrm{~min}{ }^{-1}$, and the eluted fraction (5 $\mathrm{mL}$ ) was collected with a fraction collector (Model BS-100A) and monitored at $220 \mathrm{~nm}$ using a computer ultraviolet detector (Model HD-5T). The fractions were freeze-dried and the cellular antioxidant activity was determined.

2.9.3 Reverse-phase high-performance liquid chromatography (RP-HPLC). The fraction with the highest cellular antioxidant activity obtained from gel filtration chromatography was further separated using reversed-phase high chromatography equipped with an XBridge ${ }^{\circledR}$ peptide BEH C18 column (19 $\times 250 \mathrm{~mm}, 10 \mu \mathrm{m}$, Waters, USA). The Agilent Technologies PreStar HPLC system (Agilent Technologies Inc., Santa Clara, CA, USA) consisted of two solvent delivery modules, an autosampler and a UV detector. The column was equilibrated with $0.1 \%(\mathrm{v} / \mathrm{v})$ TFA in water (Buffer A) and a linear gradient was developed using Buffer A and Buffer B: acetonitrile (ACN) containing $0.1 \%(\mathrm{v} / \mathrm{v})$ TFA. The eluent was performed with a linear gradient of ACN $(0-20 \%$ in $30 \mathrm{~min})$ containing $0.1 \%$ TFA at a flow rate of $5.0 \mathrm{~mL} \mathrm{~min}{ }^{-1}$. The fractions were monitored at $220 \mathrm{~nm}$. Peptide peaks were manually collected and evaporated to dryness in a freeze dryer (Marin Christ Inc., Osterode, Germany). The cellular antioxidant activity of all collected peaks was measured.

2.9.4 Identification of peptides by mass spectrometry. Peptide was further separated on an Acclaim PepMap RSLC column (C18, $5 \mu \mathrm{m}, 100 \AA$, $300 \mu \mathrm{m} \times 5 \mathrm{~mm})$ with a $40 \mathrm{~min}$

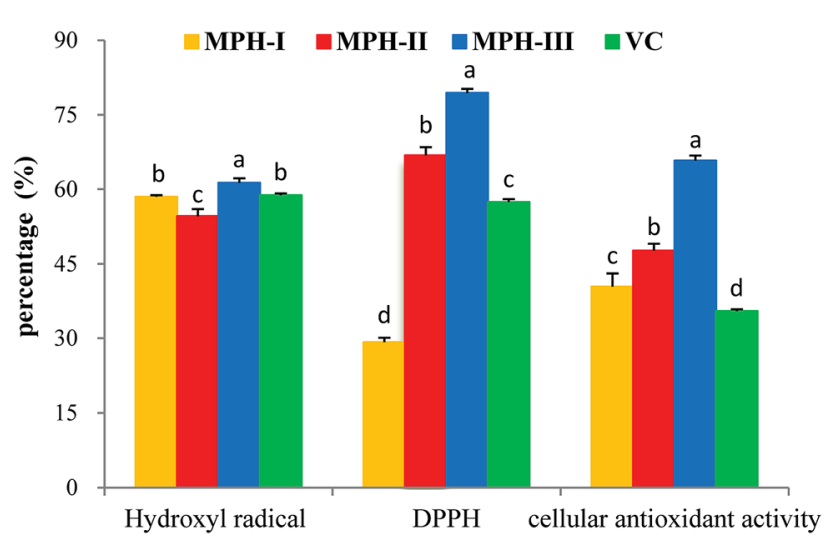

Fig. 5 Antioxidant activities of MPH with different molecular weight. In hydroxyl radical scavenging activity and $\mathrm{DPPH}$ radical scavenging activity assays, the concentrations of $\mathrm{MPH}$ and $\mathrm{VC}$ were $10 \mathrm{mg} \mathrm{mL}^{-1}$; in a cellular antioxidant activity assay, the concentration of $\mathrm{MPH}$ and $\mathrm{VC}$ was $1 \mathrm{mg} \mathrm{mL}^{-1}$. Data are presented as means $\pm \mathrm{SD}$. Bar graphs followed by different letters indicate significant differences $(P<0.05)$. 

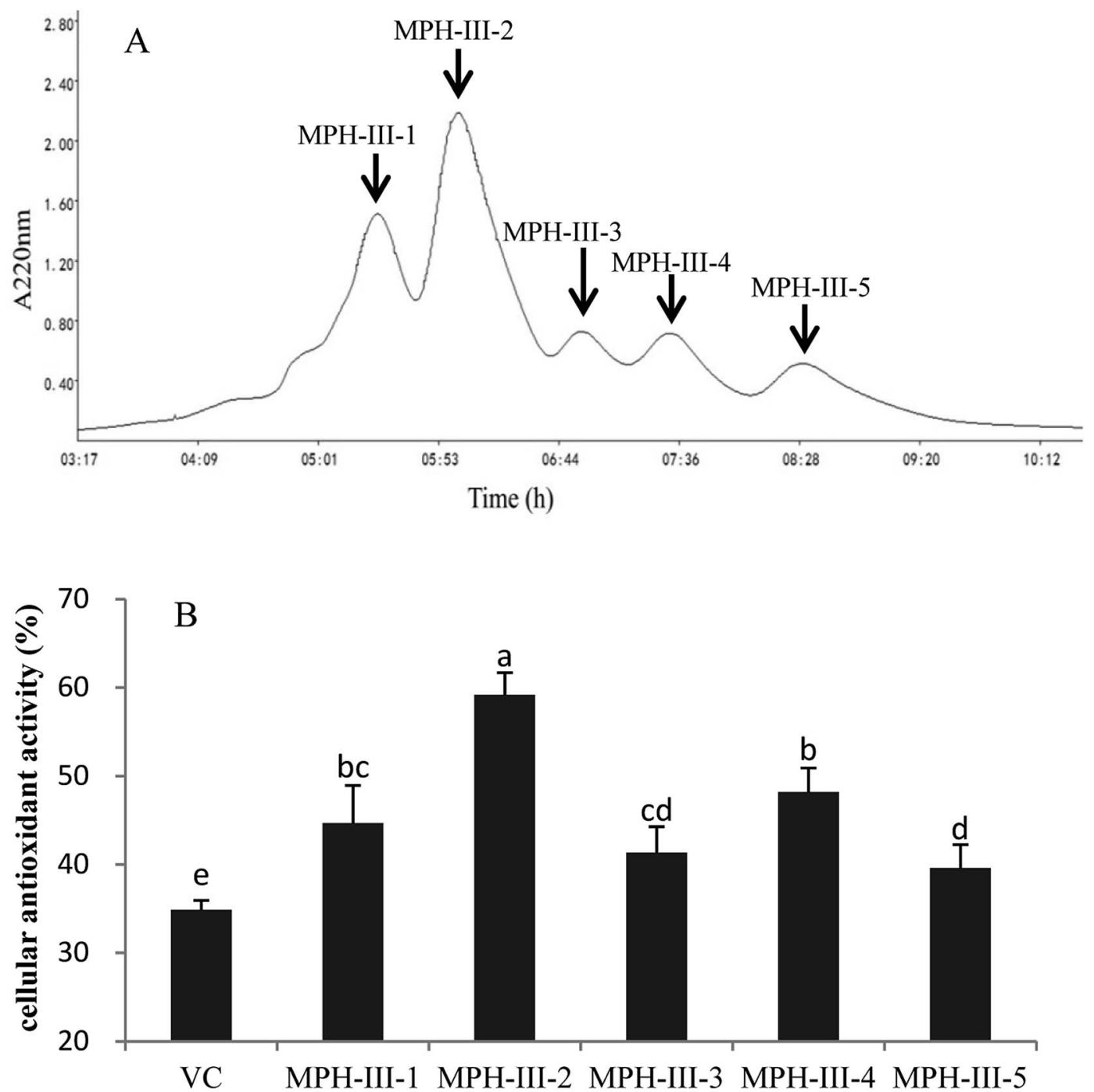

Fig. 6 Elution profile of MPH-III after ultrafiltration by Sephadex G-25 gel filtration chromatography (A) and cellular antioxidant activity of the eluted peak (B). Concentrations of fractions from MPH-III and VC were $1 \mathrm{mg} \mathrm{mL}^{-1}$. Data are presented as means \pm SD. Bar graphs followed by different letters indicated the significant differences $(P<0.05)$.

gradient of 25 min 5-50\% Buffer B (100\% ACN, 0.1\% formic acid), 10 min 50-90\% Buffer B and 5 min $90 \%$ Buffer B. Peptides were analyzed using a Thermo Scientific Q Exactive mass spectrometer in data-dependent mode with an automatic switch between MS and MS/MS scans using a top 20 method. Instrument parameters were: resolution 70000 for full MS scan and 17500 for $\mathrm{MS}^{2}$ scan, automatic gain control target $3 \times 10^{6}$ for full scan and $1 \times 10^{5}$ for $\mathrm{MS}^{2}$, maximum ion injection time $20 \mathrm{~ms}$ for full MS scan and 60 $\mathrm{ms}$ for $\mathrm{MS}^{2}$ scan.

\subsection{Statistical analysis}

Data were presented as means $\pm \mathrm{SD}$. The statistical significance of the data was determined by variance analysis (ANOVA) using SPSS software (version 18.0 for Windows, SPSS Inc., Chicago, IL, USA), and means were compared by Duncan's multiple comparison post-test. Statistical differences were considered to be significant at $p<0.05$.

\section{Results and discussion}

\subsection{Cytotoxicity effect of $\mathrm{H}_{2} \mathrm{O}_{2}$ or mackerel protein} hydrolysates (MPH) on HepG2 cells

High levels of dietary compounds can be toxic or mutagenic to cell culture systems, ${ }^{27}$ and hence, the direct effect of MPH at different concentrations on the cell viability of HepG2 cells was investigated. As shown in Fig. 1A, MPH and VC were relatively non-toxic to HepG2 cells at concentrations from $0.025 \mathrm{mg} \mathrm{mL}^{-1}$ to $10 \mathrm{mg} \mathrm{mL}^{-1}$, with cell viability more than $90 \%$. The result showed that MPH and VC had very low toxicity and that the required concentration in this range was permissible.

The effect of $\mathrm{H}_{2} \mathrm{O}_{2}$ on the cell viability of HepG2 cells was depicted in Fig. 1B. When the cells were exposed to oxidative stressors, the viability of cells decreased. ${ }^{23}$ As shown in Fig. 1B, with increasing levels of $\mathrm{H}_{2} \mathrm{O}_{2}$, cell viability decreased from $89.26 \%$ to $20.15 \%$. The result suggested that HepG2 cells were sensitive to $\mathrm{H}_{2} \mathrm{O}_{2}$. Based on the cell viability test, the level of 

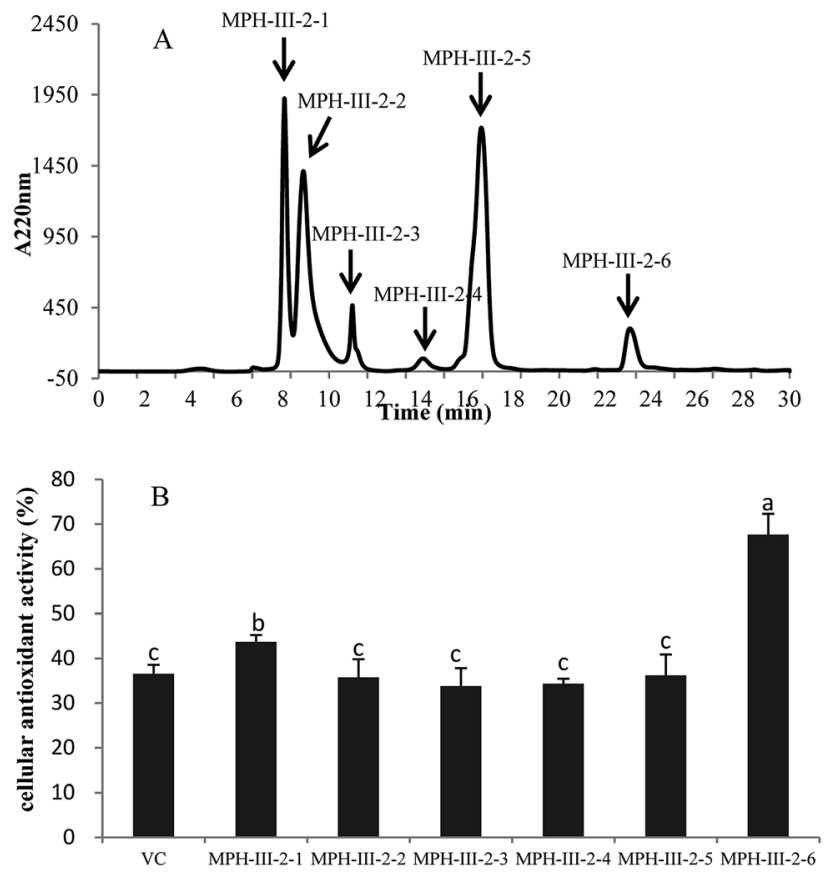

Fig. 7 Elution profile of $\mathrm{MPH}-\mathrm{III}-2$ on an XBridge ${ }^{\circledR}$ peptide $\mathrm{BEH} \mathrm{C} 18$ column (A) and cellular antioxidant activity of eluted peak (B). Concentrations of fractions from MPH-III-2 and VC were $1 \mathrm{mg} \mathrm{mL}^{-1}$. Data are presented as means $\pm S D$. Bar graphs followed by different letters indicates significant differences $(P<0.05)$.

$1000 \mu \mathrm{M} \mathrm{H}_{2} \mathrm{O}_{2}$ that led to $50 \%$ cell viability was selected to study the cellular antioxidant activity.

\subsection{Selections of proteolytic enzymes}

It is critically important to select an appropriate protease because proteases play an important role in the antioxidant activity of protein hydrolysates. ${ }^{28}$ In this study, five proteases were used for the hydrolytic production of MPH: pepsin, trypsin, papain, flavourzyme and neutrase. These proteases were selected based on their cellular antioxidant activity. As shown in Fig. 2, MPH treated with trypsin, papain and flavourzyme exhibited higher $\mathrm{DH}$ than the MPH treated with pepsin and neutrase, while MPH treated with neutrase demonstrated the highest NR (50.99\%) and cellular antioxidant activity (53.65\%), significantly different from the other four enzyme hydrolysates $(P<0.05)$. Furthermore, cellular antioxidant activity of VC group was $48.69 \%$, which was lower than the trypsin and neutrase hydrolysates. Therefore, neutrase was chosen as the best candidate for further study.

\subsection{Single factor experiments}

In this work, the effects of five single factors on cellular antioxidant activity were investigated. Fig. 3 showed that for these five single factors, the cellular antioxidant activity increased at first and reached a high point followed by a decrease. Thus, the optimal conditions were determined as follows: enzyme concentration of $1000 \mathrm{U} \mathrm{g}^{-1}$, extraction time of 4.0 hours, $\mathrm{pH}$ of 7.0 , water/material ratio of $5: 1 \mathrm{v} / \mathrm{w}$, and extraction temperature of $40{ }^{\circ} \mathrm{C}$. Furthermore, cellular antioxidant activity of VC group was $49.12 \%$.

\subsection{Optimization of extraction conditions by Box-Behnken design (BBD)}

According to the single factor experiments, the design matrix and corresponding results obtained from BBD to determine the effects of the five independent variables were listed in Table 1, and the five independent variables (enzyme concentration, extraction time, $\mathrm{pH}$, water/material ratio, extraction temperature) were coded as $A, B, C, D$ and $E$, respectively.

These results showed that cellular antioxidant activity of MPH was ranged from $35.45 \%$ to $64.08 \%$. The data were analysed via multiple regression analysis using Design-Expert software to yield the following polynomial equation:

$$
\begin{aligned}
Y= & +59.28+3.23 A+3.44 B+2.44 C+1.05 D+2.99 E+0.030 A B \\
& +0.10 A C+0.20 A D-0.59 A E-0.41 B C-1.22 B D \\
& -0.45 B E-1.08 C D+1.02 C E+0.58 D E-3.00 A^{2} \\
& -5.96 B^{2}-10.41 C^{2}-8.26 D^{2}-3.68 E^{2}
\end{aligned}
$$

The analysis of variance (ANOVA) results for the model were given in Table 2 . The corresponding variables were more significant as the $F$-value increased and the $P$-value decreased. ${ }^{29}$ The model $F$-value of 10.13 implies that the model was significant, and the $P$-value was less than 0.0500 , indicating that the model terms were significant. Additionally, the variables with significant effects $(P<0.01)$ on the cellular antioxidant activity of MPH were $A, B, C, E, A^{2}, B^{2}, C^{2}, D^{2}$ and $E^{2}$. Furthermore, the model showed good fit with the experimental data with high $R^{2}$ (89.01\%) and Adj. $R^{2}(80.22 \%)$. The low coefficient of variation $(\mathrm{CV}=6.35 \%)$ clearly suggested a high degree of precision and reliability of the experimental values. "Adeq Precision" measured the signal-to-noise ratio, and the ratio of 11.189 indicated an adequate signal. This finding suggested that the hydrolysis of MPH can be analysed and predicted by the model.

The effects of variables and their interactions on cellular antioxidant activity were illustrated by $3 \mathrm{D}$ response surfaces. The figures displayed the effects of two factors on cellular antioxidant activity, while the others were maintained at zero. ${ }^{30}$

As shown in Fig. 4A, when the enzyme concentration increased from $600 \mathrm{U} \mathrm{g}^{-1}$ to $1400 \mathrm{U} \mathrm{g}^{-1}$, the cellular antioxidant activity increased slightly; the same trend was shown in Fig. 4B$\mathrm{D}$, respectively. Additionally, the cellular antioxidant activity increased significantly when the extraction time increased from $2 \mathrm{~h}$ to $5 \mathrm{~h}$ and decreased slightly with an extraction time of $6 \mathrm{~h}$ in Fig. 4A. We inferred that the hydrolysis reaction was powerful during the first three hours and later became flat; the same trend was shown in Fig. $4 \mathrm{E}-\mathrm{G}$, respectively.

Fig. 4B showed that as the enzyme concentration increased from $600 \mathrm{U} \mathrm{g}^{-1}$ to $1400 \mathrm{U} \mathrm{g}^{-1}$, the cellular antioxidant activity increased significantly when the $\mathrm{pH}$ increased from 5 to 7 and later decreased significantly when the $\mathrm{pH}$ reached 9. Thus, $\mathrm{pH}$ was a significant factor in the experiment because each protein had a different isoelectric point, and protein solubility was 

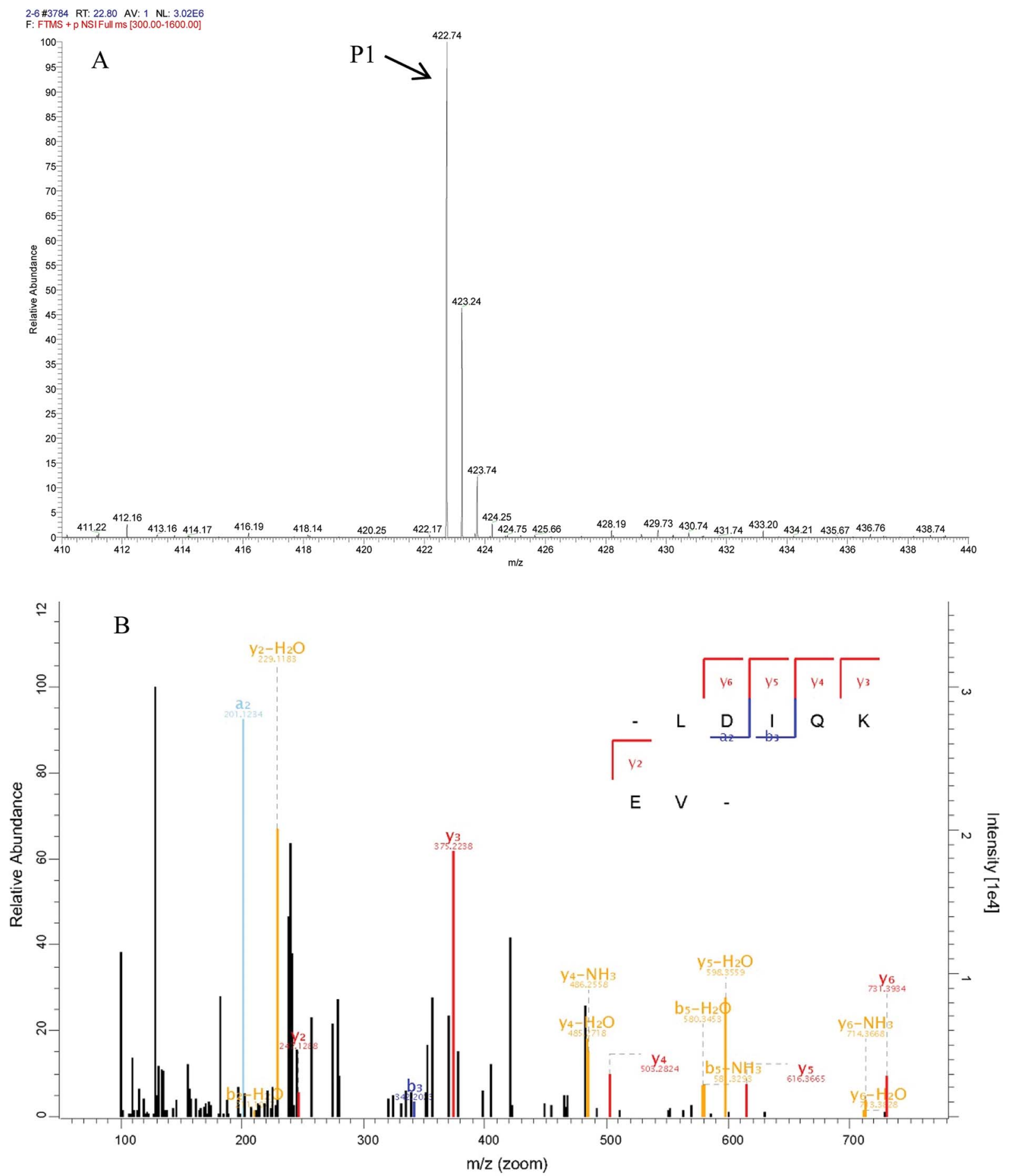

Fig. 8 Identification of molecular mass and amino acid sequence of $\mathrm{MPH}-\mathrm{III}-2-\mathrm{P} 1$. The mass spectrum of the highest active peak (P1) was acquired (A). The accurate molecular weight of P1 was determined to $843.5 \mathrm{Da}$. The collision induced fragmentation of P1 was illustrated (B). By sequence interpretation and manual calculation, the sequence of this peptide is displayed with the fragment ions observed in the MS/MS spectrum. For clarity, only $b$ and y ions are labeled.

affected by $\mathrm{pH}$. The same $\mathrm{pH}$ change trend was shown in Fig. 4E, $\mathrm{H}$ and I when another factor was changed.

Fig. 4C, F, $\mathrm{H}$ and $\mathrm{J}$ showed that when the water/material ratio increased from $1 \mathrm{v} / \mathrm{w}$ to $5 \mathrm{v} / \mathrm{w}$, the cellular antioxidant activity increased significantly, indicating that a lower water/material ratio was desirable to promote the antioxidant activity of hydrolysates; for a water/material ratio from $5 \mathrm{v} / \mathrm{w}$ to $9 \mathrm{v} / \mathrm{w}$, the cellular antioxidant activity decreased significantly.

As shown in Fig. 4D, cellular antioxidant activity increased slightly when the enzyme temperature increased from $30^{\circ} \mathrm{C}$ to 

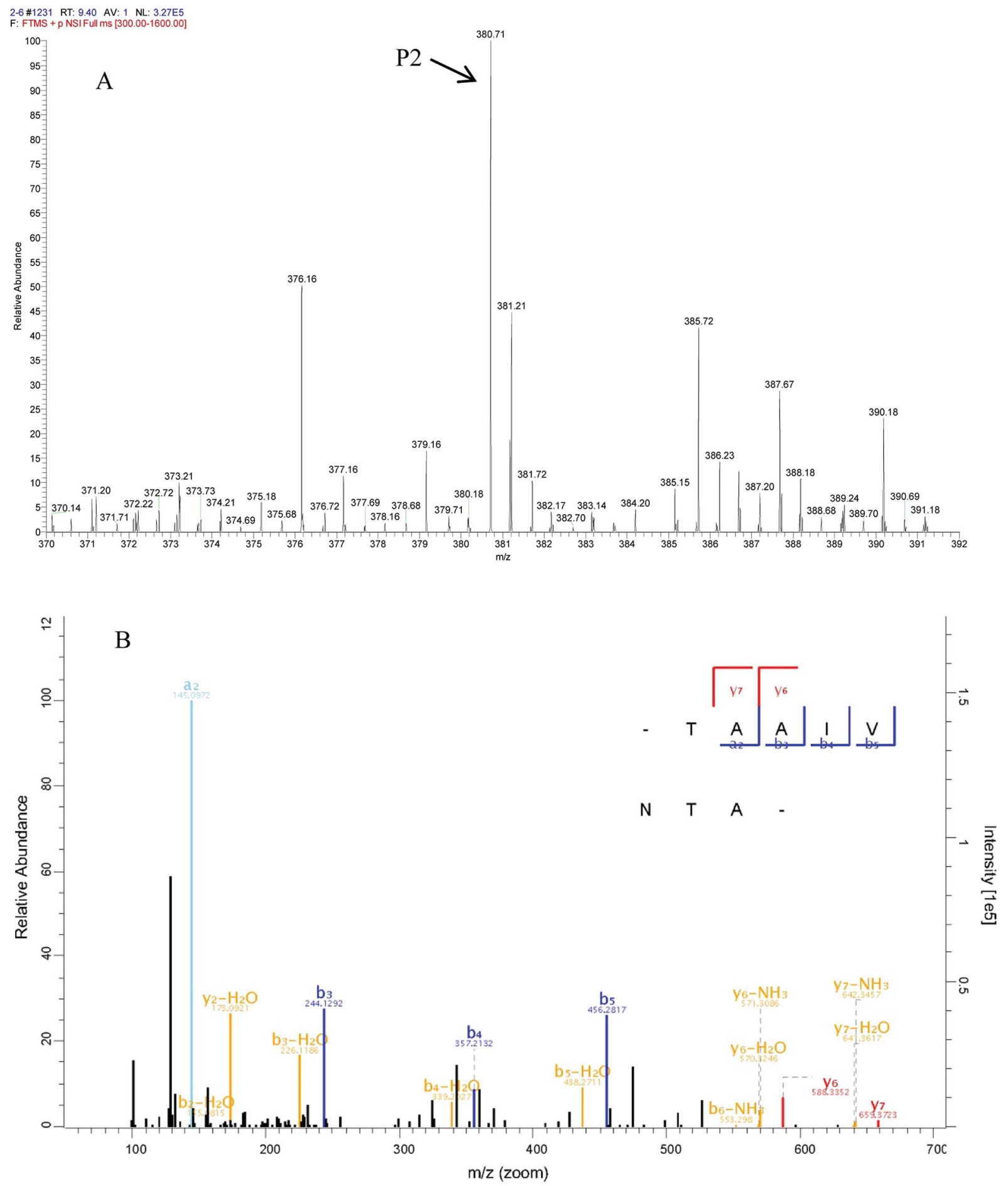

Fig. 9 Identification of molecular mass and amino acid sequence of MPH-III-2-P2. The mass spectrum of the highest active peak (P2) was acquired (A). The accurate molecular weight of P2 was determined to 759.4 Da. The collision induced fragmentation of P2 was illustrated (B). By sequence interpretation and manual calculation, the sequence of this peptide is displayed with the fragment ions observed in the MS/MS spectrum. For clarity, only $b$ and y ions are labeled.

$50{ }^{\circ} \mathrm{C}$. Within a certain temperature range, the number of active catalyst molecules increased with increasing temperature. ${ }^{31}$ The same trend was seen in Fig. 4G, I and J when another factor was changed.
Using Design-Expert 8.0, the optimal hydrolysate conditions were as follows: enzyme concentration of $1203.2 \mathrm{U} \mathrm{g}^{-1}$, extraction time of $4.53 \mathrm{~h}, \mathrm{pH}$ of 7.26 , and water/material ratio of 5.22 $\mathrm{v} / \mathrm{w}$ and extraction temperature of $43.72{ }^{\circ} \mathrm{C}$. The maximum 
cellular antioxidant activity was $61.30 \%$, which was in agreement with the experimental value.

\subsection{Purification of MPH}

UF membranes with a MWCO of 10000 Da and 3500 Da were used to separate the MPH into three fractions: MPH-I $(>10000$ Da), MPH-II (3500-10 $000 \mathrm{Da})$ and MPH-III (<3500 Da), respectively. It is well-known that antioxidant activity is affected by the size and compositional changes of peptides. ${ }^{32}$ Low-molecularweight peptides are more biologically active than the larger parent polypeptides..$^{33}$ As shown in Fig. 5, MPH-III showed the highest hydroxyl radical scavenging activity, DPPH radical scavenging activity and cellular antioxidant activity with values of $61.28 \%, 79.38 \%$ and $65.76 \%$, respectively, which were significantly higher than those of MPH-I and MPH-II $(P<0.05)$. The result was consistent with the report from You et al. ${ }^{34}$ who also observed that protein hydrolysates with molecular weight below 3000 Da had a higher antioxidant activity than other fractions. Furthermore, hydroxyl radical scavenging activity, DPPH radical scavenging activity and cellular antioxidant activity of VC were significantly lower than that of MPH-III $(P<$ 0.05). Therefore, MPH-III was used for further antioxidant assays and purification.

Gel filtration chromatography was applied to isolate protein hydrolysates according to their molecular weight. ${ }^{34}$ The most active fraction MPH-III was subjected to size exclusion chromatography using Sephadex G-25 and fractionated into five portions (Fig. 6A). Each peak was pooled and lyophilized. As shown in Fig. 6B, the cellular antioxidant activity of $\mathrm{VC}$ was significantly lower than MPH fractions and MPH-III-2 was exhibited the strongest cellular antioxidant activity of 59.16\%, which was significantly higher than those of the other fractions $(P<0.05)$.

The active fraction MPH-III-2 was further separated using RP-HPLC with an XBridge ${ }^{\circledR}$ peptide BEH C18 column, and the fraction was divided into six portions (Fig. 7A). Fraction MPHIII-2-6 showed the highest cellular antioxidant activity of $67.61 \%$ (Fig. 7B), which was significantly higher than those of the other fractions and VC group $(P<0.05)$. The results showed that peptides with the greatest retention time when eluting from the reverse phase column had the highest cellular antioxidant activity. ${ }^{34}$

In peptide identification, mass spectrometric approaches have become increasingly widely used to analyse the amino acid sequences of peptide and proteins due to their rapid, highthroughput and high sensitivity capabilities. ${ }^{35}$ According to the Thermo Scientific Q Exactive mass spectrometer, two high score peptides P1 and P2 were obtained. The precursor ion scan mass spectrum was shown in Fig. 8A and 9A, respectively. The MS/MS spectrum of two charged ions with $\mathrm{m} / \mathrm{z}$ at $422.7 \mathrm{Da}$ and 380.7 Da were shown in Fig. 8B and 9B, respectively. Following sequence interpretation and a database search, the MPH-III-2 with $\mathrm{m} / \mathrm{z}$ at $422.7 \mathrm{Da}$ was identified as the heptapeptide P1: LDIQKEV (843.5 Da); and with $\mathrm{m} / \mathrm{z}$ at 380.7 Da was identified as the octapeptide P2: TAAIVNTA (759.4 Da). This finding was consistent with other antioxidant peptides identified from fish sources with molecular weights between 500 and $1500 \mathrm{Da}^{36,37}$ The result further confirmed the general finding that short peptides with 2-20 amino acids exhibited greater antioxidant activity and other bioactive properties. ${ }^{38}$ This finding indicated that it was possible to obtain an antioxidative peptide from mackerel protein using enzymatic hydrolysis.

\section{Conclusion}

Marine low-value fish are used in many industries, and their commercial applications are expanding every year. However, their applicability as bioactive compounds and their active compositions have not been extensively studied. Based on the results in this study, it appeared that low-molecular-weight peptides obtained from neutrase-hydrolysed mackerel (Pneumatophorus japonicus) protein exhibited good antioxidant activity. The heptapeptide LDIQKEV (843.5 Da) and the octapeptide TAAIVNTA (759.4 Da) were identified from the MPH using a series of purification methods. For further development as novel antioxidative peptides, the in vivo effects of these peptides should be investigated.

\section{Conflicts of interest}

The authors declare that there is no conflict of interests regarding the publication of this paper.

\section{Acknowledgements}

The study was supported by the National Natural Science Foundation of China (No. 41506175), Key Research and Development Program of Shandong Province (2017YYSP018), Qingdao Science and Technology Project (No. 17-3-3-21-nsh) and the Key Research Program of the Chinese Academy of Sciences (No. KFZD-SW-106).

\section{References}

1 B. Halliwell, Lancet, 1994, 344, 721-724.

2 Y. H. Li, L. Wei, J. R. Cao, L. G. Qiu, X. Jiang, P. Li, Q. Q. Song, H. L. Zhou, Q. Han and X. P. Diao, Chemosphere, 2016, 144, 234-240.

3 F. Luo, R. Xing, X. Wang, H. Yang and P. Li, Int. J. Food Sci. Technol., 2017, 53, 395-403.

4 A. T. Girgih, C. C. Udenigwe, F. M. Hasan, T. A. Gill and R. E. Aluko, Food Res. Int., 2013, 52, 315-322.

5 C. F. Chi, F. Y. Hu, B. Wang, Z. R. Li and H. Y. Luo, Mar. Drugs, 2015, 13, 2580-2601.

6 R. Morales-Medina, F. Tamm, A. M. Guadix, E. M. Guadix and S. Drusch, Food Chem., 2016, 194, 1208-1216.

7 K. H. S. Farvin, L. L. Andersen, J. Otte, H. H. Nielsen, F. Jessen and C. Jacobsen, Food Chem., 2016, 204, 409-419.

8 P. J. García-Moreno, I. Batista, C. Pires, N. M. Bandarra, F. J. Espejo-Carpio, A. Guadix and E. M. Guadix, Food Res. Int., 2014, 65, 469-476.

9 M. Chalamaiah, B. Dinesh kumar, R. Hemalatha and T. Jyothirmayi, Food Chem., 2012, 135, 3020-3038. 
10 R. S. Croker, Fish. Bull., 1933, 40, 1-149.

11 K. A. M. Donnelly, M. Thakur and J. Sakai, Food Control, 2013, 33, 25-31.

12 J. H. Bae and S. Y. Lim, Food Chem. Toxicol., 2012, 50, 823828.

13 R. Perez-Galvez, R. Morales-Medina, F. Espejo-Carpio, A. Guadix and E. M. Guadix, Food Funct., 2016, 7, 3890-3901.

14 C. W. Tan, T. T. H. Malcolm, C. H. Kuan, T. Y. Thung, W. S. Chang, Y. Y. Loo, J. M. K. J. K. Premarathne, O. B. Ramzi, M. F. S. Norshafawatie, N. Yusralimuna, Y. Rukayadi, Y. Nakaguchi, M. Nishibuchi and S. Radu, Front Microbiol., 2017, 8, 1-9.

15 X. Q. Wang, H. H. Yu, R. G. Xing, X. L. Chen, S. Liu and P. C. Li, BioMed Res. Int., 2017, 1-14.

16 A. G. P. Samaranayaka and E. C. Y. Li-Chan, J. Funct. Foods, 2011, 3, 229-254.

17 N. S. Sampath Kumar, R. A. Nazeer and R. Jaiganesh, Amino Acids, 2012, 42, 1641-1649.

18 R. Morales-Medina, R. Pérez-Gálvez, A. Guadix and E. M. Guadix, Process Biochem., 2017, 52, 149-158.

19 J. A. Vazquez, P. Ramos, J. Miron, J. Valcarcel, C. G. Sotelo and R. I. Perez-Martin, Mar. Drugs, 2017, 15, 1-14.

20 W. H. Taylor, Analyst, 1957, 82, 488-498.

21 AOAC, Official Methods of Analysis, Association of Official Agricultural Chemists, Washington, DC, 14th edn, 1984.

22 S. Benjakul and M. T. Morrissey, J. Agric. Food Chem., 1997, 45, 3423-3430.

23 S. Yarnpakdee, S. Benjakul, H. Kristinsson and H. Bakken, J. Food Sci. Technol., 2015, 52, 6194-6205.
24 M. Jin, Y. X. Cai, J. R. Li and H. Zhao, Prog. Biochem. Biophys., 1996, 23, 553-555.

25 M. S. Blois, Nature, 1958, 181, 1199-1200.

26 L. Tian, J. Liu, L. Ma, L. Zhang, S. Wang, E. Yan and H. Zhu, J. Food Process. Preserv., 2017, 41, 1-11.

27 M. Alia, R. Mateos, S. Ramos, E. Lecumberri, L. Bravo and L. Goya, Eur. J. Nutr., 2006, 45, 19-28.

28 X. Fang, N. Xie, X. Chen, H. Yu and J. Chen, Food Bioprod. Process., 2012, 90, 676-682.

29 Z. Y. Zhao, Q. Zhang, Y. F. Li, L. L. Dong and S. L. Liu, Carbohydr. Polym., 2015, 119, 101-109.

30 K. Feng, W. Chen, L. Sun, J. Liu, Y. Zhao, L. Li, Y. Wang and W. Zhang, Carbohydr. Polym., 2015, 125, 45-52.

31 L. Y. Liu, Y. P. Wang, C. Peng and J. J. Wang, Int. J. Mol. Sci., 2013, 14, 3124-3139.

32 H. M. Chen, K. Muramoto, F. Yamauchi and K. Nokihara, J. Agric. Food Chem., 1996, 44, 2619-2623.

33 C. Chen, Y.-J. Chi, M.-Y. Zhao and L. Lv, Amino Acids, 2012, 43, 457-466.

34 L. You, M. Zhao, J. M. Regenstein and J. Ren, Food Res. Int., 2010, 43, 1167-1173.

35 B. Li, F. Chen, X. Wang, B. Ji and Y. Wu, Food Chem., 2007, 102, 1135-1143.

36 S. Ranathunga, N. Rajapakse and S. K. Kim, Eur. Food Res. Technol., 2006, 222, 310-315.

37 S. Y. Jun, P. J. Park, W. K. Jung and S. K. Kim, Eur. Food Res. Technol., 2004, 219, 20-26.

38 P. R. Roberts, J. D. Burney, K. W. Black and G. P. Zaloga, Digestion, 1999, 60, 332-337. 